\title{
Critical defining characteristics for nursing diagnosis about ineffective breastfeeding
}

\author{
Características definidoras críticas para o diagnóstico de enfermagem acerca da amamentação ineficaz
}

Características determinantes cruciales para el diagnóstico de enfermería acerca de la lactancia ineficaz

\section{Sandra Cristina de Alvarenga', Denise Silveira de Castro', Franciéle Marabotti Costa Leite", Telma Ribeiro Garcia"', Marcos Antônio Gomes Brandão'v , Cândida Caniçali Primo ${ }^{\text {I,IV }}$}

'Universidade Federal do Espírito Santo, Center of Health Sciences, Postgraduate Program in Nursing. Vitória, Espírito Santo, Brazil. "Universidade Federal do Espírito Santo, Center for Health Sciences, Department of Nursing. Vitória, Espírito Santo, Brazil.

"'Universidade Federal da Paraíba, Department of Public Health and Psychiatry Nursing. João Pessoa, Paraíba, Brazil.

"Universidade Federal do Rio de Janeiro, Anna Nery Nursing School, Postgraduate Program in Nursing. Rio de Janeiro, Brazil.

How to cite this article:

Alvarenga SC, Castro DS, Leite FMC, Garcia TR, Brandão MAG, Primo CC. Critical defining characteristics for nursing diagnosis about ineffective breastfeeding. Rev Bras Enferm [Internet]. 2018;71(2):314-21.

DOI: http://dx.doi.org/10.1590/0034-7167-2016-0549

Submission: 11-11-2016 Approval: 04-11-2017

\begin{abstract}
Objective: To investigate the Nursing diagnostic accuracy measures and to propose a model to use defining characteristics in order to judge the nursing diagnosis of ineffective breastfeeding. Method: Cross-sectional study with a sample of 73 binomials mom-child hospitalized in a maternity ward of an University Hospital, from July to August of 2014. Results: The diagnostic predominance rate was $58.9 \%$. The characteristics that best meet the needs of logistic regression model were: discontinuance of breast sucking; infant's inability of seizing the areola-nipple region correctly; infant's crying one hour after breastfeeding and inappropriate milk supply perceived. Conclusion: Breastfeeding process is dynamic; diagnostic judgement may suffer some changes according to the time data are collected; the defining characteristics are the best predictors if associated with models and rules of use.
\end{abstract}

Descriptors: Breastfeeding; Nursing Diagnostic; Weaning; Classification; Nursing Processes.

\section{RESUMO}

Objetivo: Investigar as medidas de acurácia diagnóstica de enfermagem e propor um modelo para uso de características definidoras no julgamento do diagnóstico de enfermagem de amamentação ineficaz. Método: Estudo transversal, com amostra de 73 binômios mãe-filho internados na Maternidade de um Hospital Universitário no período de julho a agosto de 2014. Resultados: A prevalência do diagnóstico foi de $58,9 \%$. As características que melhor atenderam ao modelo de regressão logística foram: descontinuidade da sucção da mama; incapacidade do lactente de apreender a região aréolo-mamilar corretamente; ocorrência de choro do lactente na primeira hora após a amamentação e suprimento de leite inadequado percebido. Conclusão: O processo de amamentação é dinâmico; o julgamento diagnóstico pode sofrer modificações conforme o tempo em que o dado é coletado; as características definidoras são melhores preditoras se associadas com modelos e regras de utilização.

Descritores: Aleitamento Materno; Diagnóstico de Enfermagem; Desmame; Classificação; Processos de Enfermagem.

\section{RESUMEN}

Objetivo: Investigar las medidas de exactitud diagnóstica de enfermería y proponer un modelo para el uso de características determinantes en el juicio del diagnóstico de enfermería de lactancia ineficaz. Método: Estudio transversal, con muestra de 73 binomios madre-hijo hospitalizados en la Maternidad de un Hospital Universitario en el período de julio a agosto de 2014. Resultados: La prevalencia del diagnóstico fue del 58.9\%. Las características que mejor atendieron al modelo de regresión logística fueron: discontinuidad de la succión de la mama; incapacidad del lactante para agarrar la región aréola-mamilar correctamente; la ocurrencia de llanto del lactante a la primera hora después de la lactancia y el suministro de leche inadecuada 
percibido. Conclusión: El proceso de lactancia es dinámico; el juicio diagnóstico puede sufrir modificaciones según el tiempo en que se recoja el dato; las características determinantes son mejores predictores si se asocian con modelos y reglas de uso.

Descriptores: Lactancia Materna; Diagnóstico de Enfermería; Desmame; Clasificación; Procesos de Enfermería.

\section{CORRESPONDING AUTHOR Cândida Caniçali Primo E-mail: candida.primo@ufes.br}

\section{INTRODUCTION}

Breastfeeding is a phenomenon of high relevance for women and children's health, having different possibilities of definitions. From a conceptual point of view, it can be understood as a biopsychosocial process of dynamic relationship between a woman and a child, which is initiated at a specific interval after birth, with different levels of efficacy in terms of provision and breastmilk receiving during each feeding session ${ }^{(1)}$.

In Brazil, the Ministry of Health, dealing with the nutrition of the child in a publication addressed to primary care, recognizes that breastfeeding is much more than nurturing and highlights the role of the health professional to increase breastfeeding rates in Brazil. Thus, it is imperative that health professionals be able to advise on techniques and interventions for problems related to breastfeeding ${ }^{(2)}$.

In the context of health actions, nurses are professionals who are commonly engaged in advising and monitoring of breastfeeding, which requires that their clinical judgment and judgment capacity be continually improved. For clinical judgment to be appropriate, evidence is needed for a construct and a professional diagnoses that represent a conclusion about a phenomenon that is being observed and that drives the professional action. The nursing diagnosis is a method of reasoning, evaluation and judgment, which requires a cognitive process and intellectual skills, as well as practical experience and scientific knowledge. It is based on the presence of clinical evidences / inferences that can be observed, and on the analysis of factors related to the observed phenomenon, which may be occurring with the client, the family or the community ${ }^{(3-5)}$.

Among the nursing diagnosis classification systems, the International NANDA (NANDA-I)(6)'s taxonomy stands out, which is one of the most applied and used worldwide in the process of reasoning and clinical judgment about health problems or vital processes. Notwithstanding the value's recognition of nursing diagnosis as an instrument for reasoning and judgment, there is still a dimension of experience or response that is the object of this cognitive process, the diagnostic concept itself.

NANDA- $\left.\right|^{(6)}$ classifies three nursing diagnoses related to breastfeeding: ineffective breastfeeding, discontinued breastfeeding, and disposition for increased breastfeeding. The present study investigates the nursing diagnosis of ineffective breastfeeding, being defined as a "difficulty to offer milk to an infant or young child directly from the breasts, which may undermine the nutritional status of the infant or child". To support the establishment of nursing diagnoses, such as ineffective breastfeeding, NANDA-I presents defining characteristics, that is, "observable indicators or inferences that group together as manifestations of a diagnosis that focus on problem, on health promotion or syndrome $\mathrm{e}^{\prime \prime(6)}$.

The objective of the present study is to investigate the diagnostic accuracy measures and to propose a model for the use of defining characteristics in the judgment of the nursing diagnosis about ineffective breastfeeding.

\section{METHOD}

\section{Ethical aspects}

The study met the ethical recommendations and approved by the Ethics and Research Committee, on 06.25.2014.

\section{Study's design, place and period of time}

This cross-sectional study was carried out with given birth and infants hospitalized in the maternity ward of a public tertiary hospital in Vitória, Espírito Santo state, in the southeastern of Brazil, from July to August of 2014. The institution provides a wide range of health care assistance to the population of the state of Espírito Santo and cities of the state of Bahia and Minas Gerais, both in high complexity needs and in primary and secondary health needs. The maternity has 20 beds and adopts the system of joint accommodation for the mother to look after her infant 24 hours a day.

\section{Sample and inclusion and exclusion criteria}

The sample was obtained through convenience and was composed of 73 binomials, after evaluation of the following exclusion criteria: given birth who had a personal or family records of psychiatric illness; who could not breastfeed because of infectious disease; who were illicit drug users or did not live in the large city of Vitória, ES.

\section{Data collection and organization}

For binomial evaluation, we used a data collection instrument of authors, containing: defining characteristics of ineffective breastfeeding(6); clinical and obstetrical sociodemographic data derived from nursing research and protocols and institutional manuals. The variables were organized into five sections of the instrument: 1) maternal characterization data; 2) clinical evaluation of breasts; 3) breastfeeding evaluation; 4) characterization data of the infant; 5) binomial attitudes and/or behaviors during breastfeeding. The operational definitions for the defining characteristics were available to those who would apply the instrument.

The data were collected through interviews, medical records, physical examination and clinical observation of the binomial during the feeding within 48 (forty-eight) hours after birth. Two subsequent evaluations occurred after seven days, and then, thirty. In the present study, data from the first evaluation performed within 48 hours after birth were used.

In order to reduce the benchmarking bias, the three evaluators were: a researcher with clinical experience in the area and two nursing students in the final quarter of the course, all trained in the area. These three evaluators were trained in a 10-hour course on semiology and semi-technical breastfeeding, nursing 
diagnosis of ineffective breastfeeding and evaluation criteria, with operational definitions for the defining characteristics, and detailed conceptions and instructions to use the instrument. The performance of the evaluators in the data collection was evaluated by another researcher with greater clinical experience and expertise in performing a pilot test with ten mother / baby binomials, and the general agreement of the evidence reached was greater than $85 \%$ being considered valid.

For the diagnostic decision about whether or not the diagnosis of ineffective breastfeeding's presence, the data collected from the binomials, organized in a spreadsheet, were submitted to the judgment of two researchers with clinical experience and expertise in the area, being recommended for their decision to: (a) take into account the case data (binomials); (b) consider the diagnostic definition of NANDA-I for ineffective breastfeeding; and (c) consider the diagnosis only when there are at least three defining characteristics. The decision to consider at least three defining characteristics was based on the nature of the diagnosis and for which, in a pilot study, the high prevalence of some characteristics that tended to form patterns of association was verified. In addition, NANDA-I corroboration was considered that there are diagnoses requiring group of symptoms in order to obtain accuracy ${ }^{(6)}$.

\section{Analysis of results and statistics}

In the analysis of the data, the measures of accuracy of defining characteristics were: sensitivity, specificity, efficiency, odds ratio and positive and negative predictive values.

Accuracy measures were obtained by the Instat Graphpad $^{\circledR}$ software and the Excel ${ }^{\circledR}$-based DAG STAT software. The confidence interval adopted was $95 \%$ and the statistical significance was verified by Fishers exact test. The defining characteristics with appropriate measures of accuracy were those that reached: Efficiency (EF) equal to or greater than $70 \%$ and Odds Ratio (OR*) greater than 1.0. Considering that some cell values were zero and reduced, we chose to use the Haldane estimator $\left(\mathrm{OR}^{*}\right)$, increasing confidence in the results obtained.

Logistic regression was calculated by the MEDCALC ${ }^{\circledR}$ statistical software $^{(7)}$. The regression represented the statistical method used, in order to analyze which model would be best to describe the relationship between the dichotomous dependent variable (presence or absence of the nursing diagnosis) and the set of independent variables (defining characteristics) that would act as predictors or explainers of ineffective breastfeeding.

For the defining characteristics included in the logistic regression model, the positive and negative predictive values were worked by an inclusion and discard rule of the diagnosis that seeks to synthesize these values also considering the prevalence $^{(8)}$. For the use of the inclusion and exclusion rule, the following formulas and interpretations were proposed: the chances of having CD (DeCD) = PPV; chances of diagnosis not having $\mathrm{CD}($ DenCD) $=1-\mathrm{NPV}$; inclusion index $(\mathrm{Ii})=$ DeCD-Prevalence; exclusion index $(\mathrm{Ei})=$ DenCD-Prevalence.

The decision will be given by considering a given defining characteristic is more useful to include a case such as probable diagnosis if $\mathrm{Ii}>\mathrm{Ei}$ (inclusion value); because it considers that a given defining characteristic is more useful to include a case as without the diagnosis if li < Ei (exclusion value) or without a prominent inclusion or exclusion value when $l i=E i$.

In the discussion about the data, the characteristic's model was also worked on in its clinical reasonability to function systemically in order to explain the occurrence of ineffective breastfeeding during the first 48 hours of the infant's life.

\section{RESULTS}

In the sociodemographic profile, the majority $(79.5 \%)$ of the given birth was 34 years of age, $63 \%$ had no partner and $71.2 \%$ had more than eight years of study. As for infants, $58.9 \%$ were female and $90.4 \%$ were full-term (born over 37 weeks of gestation).

Using the evaluation of nursing diagnosis of ineffective breastfeeding, it was verified that there was evidence for a prevalence of $58.9 \%$. Table 1 presents the distribution frequency of defining characteristics in cases with and without this nursing diagnosis.

As observed in Table 1, the infant's inability of seizing the areola-nipple region correctly, absence of observable signs of oxytocin release, and discontinuance of breast sucking were present in most of the binomials investigated. Whereas, the lower frequencies were: discontinuance of breast sucking and insufficient drainage of the breast when breastfeeding. Table 2 presents the accuracy measures adopted in the present study, referring to the values calculated from the research in the 73 binomials.

Efficacy (EF) or accuracy, were found to be the highest values for the characteristics: the infant's inability of seizing the areola-nipple region correctly $(\mathrm{EF}=86.3 \%)$ and inappropriate milk supply perceived $(\mathrm{EF}=79.5 \%)$.

The positive predictive value $(83.7 \%)$ and negative predictive value $(91.7 \%)$ of the infant's inability of seizing the areola-nipple region correctly form the best probability of occurrence's set of ineffective breastfeeding in the presence of this characteristic (PPV) and absence of ineffective breastfeeding when the characteristic is not found (NPV).

The Odds Ratio (OR) of the infant's inability of seizing the areola-nipple region correctly indicates that, their presence increases the chance of ineffective breastfeeding by 56 times; the resistance of the infant in seizing the nipple region with the mouth does so in 30 times; the occurrence of crying of the infant when it is put on the breast occurs in 27 times; inappropriate milk supply perceived 18.9 times; discontinuance of breast sucking by 16.1 times; and the absence of observable signs of oxytocin release does so by 8.2 -fold (only characteristics that had OR $>1.0$ in the lower range).

Considering the complexity of the interpretation of the separate characteristics statistics, the logistic regression was applied to verify the most appropriate model of characteristics associated to the diagnosis of ineffective breastfeeding (Table 3).

According to results contained in Table 3, among the eleven characteristics studied, four were considered significant by the Wald test ( $p<0.05$ ), to estimate ineffective breastfeeding in stepwise logistic regression. The seven other characteristics were removed from the model because they did not reach significance value during the regression. In the model, the Odds Ratio values of the four defining characteristics - expressed in how many times the chance of ineffective breastfeeding 
occurs in cases where the characteristic was found - would be greater than in cases where they were not found, thus generating a hierarchy of chances: discontinuance of breast suction (197 times); inappropriate milk supply perceived (186 times); infant's inability of seizing the areola-nipple region correctly (167 times); and infant's crying one hour after breastfeeding (99 times).

The chi-square value indicates the regression model of the four mentioned characteristics explains in $78.313 \%$ the occurrence of ineffective breastfeeding in the sample studied. The
R2 values of Cox \& Snell (0.6579) and Nagelkerke (0.8868) indicate the adequacy of the proposed model.

By applying the inclusion and exclusion rule using the values contained in Table 2 and the prevalence of $58.9 \%$, the following inclusion indexes (li) and exclusion indexes (Ei) are obtained for the four defining characteristics of the model: : discontinuance of breast suction ( $\mathrm{li}=33.1$ and $\mathrm{Ei}=17.2$ ); inappropriate milk supply perceived ( $\mathrm{Ii}=30.0$ and $\mathrm{Ei}=29.2$ ); infant's inability of seizing the areola-nipple region correctly ( $\mathrm{li}=24.8$ and $\mathrm{Ei}=50.6)$; and infant's crying one hour after breastfeeding ( $\mathrm{li}=16.1$ and $\mathrm{Ei}=4.5)$.

Table 1 - Distribution frequency of defining characteristics related to the diagnosis of nursing of ineffective breastfeeding

Defining characteristics

\section{Ineffective breastfeeding}

Yes

No Total

n

$\%$

n

$\% \quad \mathrm{n}$

Absence of observable signs of oxytocin release

Yes

No

Discontinuance of breast sucking

Yes

No

Insufficient drainage of the breast when breastfeeding

Yes

No

Infant's inability of seizing the areola-nipple region correctly

Yes

No

Occurrence of crying of the infant when it is put on the breast

Yes

No

Infant's crying one hour after breastfeeding

Yes

No

Infant's excitement one hour after breastfeeding

Yes

No

Infant's bending on the breast

Yes

No

Insufficient opportunity of sucking the breast

Yes

No

Resistance of the infant in seizing the nipple region with the mouth

Yes

No

Inappropriate milk supply perceived

Yes

No

\begin{tabular}{|c|c|c|c|c|c|}
\hline 24 & 32.9 & 4 & 5.5 & 28 & 38.4 \\
\hline 19 & 26.0 & 26 & 35.6 & 45 & 61.6 \\
\hline 23 & 31.5 & 2 & 2.7 & 25 & 34.2 \\
\hline 20 & 27.4 & 28 & 38.4 & 48 & 65.8 \\
\hline 5 & 6.8 & 0 & 0.0 & 5 & 6.8 \\
\hline 38 & 52.1 & 30 & 41.1 & 68 & 93.2 \\
\hline 41 & 56.2 & 8 & 11.0 & 49 & 67.1 \\
\hline 2 & 2.7 & 22 & 30.1 & 24 & 32.9 \\
\hline 13 & 17.8 & 0 & 0.0 & 13 & 17.8 \\
\hline 30 & 41.1 & 30 & 41.1 & 60 & 82.2 \\
\hline 12 & 16.4 & 4 & 5.5 & 16 & 21.9 \\
\hline 31 & 42.5 & 26 & 35.6 & 57 & 78.1 \\
\hline 5 & 6.8 & 6 & 8.2 & 11 & 15.1 \\
\hline 38 & 52.1 & 24 & 32.9 & 62 & 84.9 \\
\hline 6 & 8.2 & 0 & 0.0 & 6 & 8.2 \\
\hline 37 & 50.7 & 30 & 41.1 & 67 & 91.8 \\
\hline 9 & 12.3 & 2 & 2.7 & 11 & 15.1 \\
\hline 34 & 46.6 & 28 & 38.4 & 62 & 84.9 \\
\hline 14 & 19.2 & 0 & 0.0 & 14 & 19.2 \\
\hline 29 & 39.7 & 30 & 41.1 & 59 & 80.8 \\
\hline 32 & 43.8 & 4 & 5.5 & 36 & 49.3 \\
\hline 11 & 15.1 & 26 & 35.6 & 37 & 50.7 \\
\hline
\end{tabular}


Table 2 - Accuracy measures of defining characteristics related to the diagnosis of nursing of ineffective breastfeeding

\section{Defining characteristics}

\begin{tabular}{cccccccccc}
\multicolumn{1}{c}{ Diagnostic accuracy measures } \\
SP & Low & High & ES & Low & High & EF & Low & High & $p$ value \\
$\%$ & $\%$ & $\%$ & $\%$ & $\%$ & $\%$ & $\%$ & $\%$ & $\%$ &
\end{tabular}

$\begin{array}{llllllllll}55.8 & 39.9 & 70.9 & 86.7 & 69.3 & 96.2 & 68.5 & 56.6 & 78.9 & \mathbf{0 . 0 0 0 2} *\end{array}$ $\begin{array}{llllllllll}53.5 & 37.7 & 68.8 & 93.3 & 77.9 & 99.2 & 69.9 & 58.0 & 80.1 & <\mathbf{0 . 0 0 0 1}\end{array}$ $\begin{array}{llllllllll}11.6 & 3.9 & 25.1 & 100.0 & 88.4 & 100.0 & 47.9 & 36.1 & 60.0 & 0.0736\end{array}$ $\begin{array}{llllllllll}95.3 & 84.2 & 99.4 & 73.3 & 54.1 & 87.7 & 86.3 & 76.2 & 93.2 & <\mathbf{0 . 0 0 0 1}\end{array}$ $\begin{array}{llllllllll}30.2 & 17.2 & 46.1 & 100.0 & 88.4 & 100.0 & 58.9 & 46.8 & 70.3 & \mathbf{0 . 0 0 0 5} *\end{array}$ $\begin{array}{llllllllll}27.9 & 15.3 & 43.7 & 86.7 & 69.3 & 96.2 & 52.1 & 40.0 & 63.9 & 0.1623\end{array}$ $\begin{array}{llllllllll}11.6 & 3.9 & 25.1 & 80.0 & 61.4 & 92.3 & 39.7 & 28.5 & 51.9 & 0.3422\end{array}$ $\begin{array}{llllllllll}14.0 & 5.3 & 27.9 & 100.0 & 88.4 & 100.0 & 49.3 & 37.4 & 61.3 & 0.0393 *\end{array}$ $\begin{array}{llllllllll}20.9 & 10.0 & 36.0 & 93.3 & 77.9 & 99.2 & 50.7 & 38.7 & 62.6 & 0.1110\end{array}$ $\begin{array}{llllllllll}32.6 & 19.1 & 48.5 & 100.0 & 88.4 & 100.0 & 60.3 & 48.1 & 71.5 & \mathbf{0 . 0 0 0 4} *\end{array}$ $\begin{array}{llllllllll}74.4 & 58.8 & 86.5 & 86.7 & 69.3 & 96.2 & 79.5 & 68.4 & 88.0 & <\mathbf{0 . 0 0 0 1} *\end{array}$ $\begin{array}{llllllllll}8.2 & 2.4 & 27.6 & 85.7 & 67.3 & 96.0 & 57.8 & 42.2 & 72.3 & \mathbf{0 . 0 0 0 2} *\end{array}$ $\begin{array}{lllllllllll}16.1 & 3.4 & 76.2 & 92.0 & 74.0 & 99.0 & 58.3 & 43.2 & 72.4 & <\mathbf{0 . 0 0 0 1 *}\end{array}$ $\begin{array}{llllllllll}11.3 & 0.6 & 211.3100 .0 & 47.8 & 100.0 & 44.1 & 32.1 & 56.7 & 0.0736\end{array}$ $\begin{array}{llllllllll}56.4 & 11.0 & 288.9 & 83.7 & 70.3 & 92.7 & 91.7 & 73.0 & 99.0 & <\mathbf{0 . 0 0 0 1} \text { * }\end{array}$

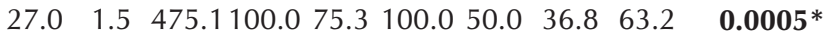
$\begin{array}{lllllllllll}2.5 & 0.7 & 8.7 & 75.0 & 47.6 & 92.7 & 45.6 & 32.4 & 59.3 & 0.1623\end{array}$ $\begin{array}{llllllllll}0.5 & 0.1 & 1.9 & 45.5 & 16.7 & 76.6 & 38.7 & 26.6 & 51.9 & 0.3422\end{array}$ $\begin{array}{lllllllll}10.6 & 0.6 & 195.4100 .0 & 54.1 & 100.0 & 44.8 & 32.6 & 57.4 & 0.0393 *\end{array}$ $\begin{array}{llllllllll}3.7 & 0.7 & 18.6 & 81.8 & 48.2 & 97.7 & 45.2 & 32.5 & 58.3 & 0.1110\end{array}$ $\begin{array}{lllllllll}30.0 & 1.7 & 526.2100 .0 & 76.8 & 100.0 & 50.8 & 37.5 & 64.1 & \mathbf{0 . 0 0 0 4} *\end{array}$

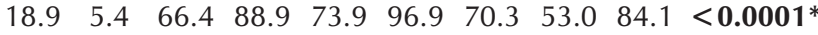
Inappropriate milk supply perceived

Note: $(S E)=$ sensitivity; $(S P)=$ specificity; $(E F)=$ test efficiency or accuracy; $\left(O R{ }^{*}\right)=$ odds ratio with Haldane estimator for zero value cells; $(P P V)=$ positive predictive value; $(N P V)=$ Negative predictive value; (Low.) and (High.) = Lower and higher values at $95 \%$ Cl; $\left(^{*}\right)$ significant value of $p$ in the Fisher's exact test. In bold, defining characteristics with $E F$ greater than or equal to $70 \%$.

Table 3 - Logistic regression for the defining characteristics of ineffective breastfeeding

\begin{tabular}{|c|c|c|c|c|c|c|}
\hline Defining characteristics & Coefficient & Standard error & Wald & Odds ratio & Limits (Cl 95\%) & $p$ value \\
\hline Discontinuance of breast sucking & 5.28397 & 1.90360 & 7.7049 & 197.1502 & 4.7252 a 8225.7355 & 0.005 \\
\hline $\begin{array}{l}\text { Infant's inability of seizing the areola-nipple } \\
\text { region correctly }\end{array}$ & 5.12074 & 1.46784 & 12.1704 & 167.4591 & 9.4288 a 2974.1483 & 0.0005 \\
\hline Infant's crying one hour after breastfeeding & 4.59100 & 1.85159 & 6.1479 & 98.5926 & 2.6166 a 3714.9224 & 0.0132 \\
\hline Inappropriate milk supply perceived & 5.22807 & 1.61086 & 10.5334 & 186.4326 & 7.9311 a 4382.3896 & 0.0012 \\
\hline Constant & -7.1611 & & & & & \\
\hline Chi-square & DF & Significance & \multicolumn{2}{|c|}{$\mathrm{R}^{2}$ of Cox \& Snell } & \multicolumn{2}{|l|}{$\mathrm{R}^{2}$ of Nagelkerke } \\
\hline 78.313 & 4 & $p<0.0001$ & \multicolumn{2}{|c|}{0.6579} & \multicolumn{2}{|l|}{0.8868} \\
\hline
\end{tabular}

Note: Wald $=$ Wald test; $\mathrm{Cl} 95 \%=$ confidence interval

\section{DISCUSSION}

The findings confirm the presence of defining characteristics (CDs) related to NANDA-International's ineffective breastfeeding diagnosis.

The comparison between the prevalence of CDs found in this study and in other studies, needs to be done carefuly. From the four characteristics incorporated into the logistic regression model, it is possible to verify the prevalences were different from those found during the first postpartum day ${ }^{(4)}$ and in later appointments in the Family Health Strategy ${ }^{(5)}$. Such evidence is relevant for the contextualized interpretation of the data and the consequent application of the results of diagnostic research in the field of care and diagnostic accuracy.

Therefore, it is relevant to understand the role of temporal circumstance in the identification of a clinical indicator. In a study performed with binomials in joint housing, the inability to seize the aoreola-nipple region (previously termed the Infant's inability of seizing the areola-nipple region correctly) had a decreasing occurrence between the first and fourth days after delivery ${ }^{(4)}$. 
Thus, the influence of the moment at which the clinical indicator is evaluated would be adjusted, pointing to a probable temporal dynamics in the characterization of ineffective breastfeeding diagnosis. This article presents results related to the evaluation of the binomial performed within the first 48 hours after delivery and, as such, should have its contribution limited to this time interval.

It is also difficult to state the real explanatory reasons for the differences in the prevalence of the diagnosis of ineffective breastfeeding of $58.9 \%$ found in the study compared to $64 \%$ and $80.2 \%$ found in other studies ${ }^{(4-5)}$. Among the explanatory possibilities: issues inherent to the diagnosis (different operational definitions for the defining characteristics and different criteria for the diagnostic decision), questions inherent to the diagnosist (different levels of expertise in the area and diagnosis), issues inherent to the participants (different characteristics of the different programs, protocols and programs of professional action, different systems of social-family support). It is understood that all these aspects require rigor and caution to ensure only the comparison between clearly aligned studies.

Logistic regression demonstrated that four defining characteristics were better in a prediction model or explanation of the occurrence of ineffective breastfeeding in nursing evaluations within 48 hours postpartum. However, statistics can only measure aspects related to numbers, and it is up to researchers to judge their clinical reasonableness. Thus, the analysis of explanations and relations will be carried out in the interests of better sustaining the statistical model.

Discontinuance of breast suction is due to the fact that some infants can not adequately seize the areola or can not hold the grab. This event can happen because the baby is not well positioned, does not open his mouth enough, or may be exposed to the bottle and / or pacifier, or the child may not properly pick up the breast because they are very tense, engorged, or the nipples are inverted or flat ${ }^{(2,9)}$.

Regarding the second characteristic with higher Odds Ratio in the model, it is known that the negative stimuli of fear, pain, anger, anxiety, frustration or stress are able to inhibit the release of oxytocin, preventing the milk ejection reflex, decreasing the supply of milk to the baby ${ }^{(10)}$, thus justifying the inappropriate milk supply perceived.

Milk is withdrawn through the tongue, thanks to a rhythmic peristaltic movement of the tip of the tongue backwards, which gently compresses the nipple. Failure of this mechanism may result from the infant's inability to seize the nipple region with the mouth. As a consequence, there may be resistance of the infant in seizing the nipple region with the mouth. And among the factors that contribute to these two characteristics it is found the difficulty of nipple seizing due to prematurity, low weight, oral dysfunction or hypoglycemia that makes the child excessively sleepy ${ }^{(11-12)}$.

The fourth defining characteristic of the regression model refers to when there is the infant's crying one hour after breastfeeding. Crying, associated with hunger, is sustained by culture as a result of problems related to milk production/ quality ${ }^{(13-14)}$. Studies show that child crying and hunger are determinants for complementary feeding for mothers before completing six months of exclusive breastfeeding ${ }^{(15-16)}$.
However, there are many reasons for crying, including from extra uterine adaptation to very tense environments. Infants generally calm down if they are cuddled or placed in the chest, which corroborates the need to feel protected and safe. Most of the time mothers become anxious, tense and frustrated with the child's crying, tending to convey these feelings to them, and as a consequence, causing more crying, if there is a vicious cycle ${ }^{(17)}$.

In the presence of a given defining characteristic, positive predictive value would indicate the chance of having the diagnosis; the greater the value of the difference of the PPV in relation to the prevalence (PPV-P), the more useful the CD for a rule of inclusion of the case in the diagnosis. In the absence of a given defining characteristic, the negative predictive value would indicate the chance of not being diagnosed. The higher the value of the NPV difference compared to the prevalence (NPV-P), the more useful the CD for a rule to exclude the case out of the diagnostic hypothesis (exclusion).

In the study, discontinuance oficial breast sucking items and infant's crying one hour after breastfeeding would be better criteria to consider the presence of ineffective breastfeeding when such characteristics were verified, than to consider their absence to rule out the diagnosis. This naturally converges to the high specificity values of the mentioned characteristics.

The inappropriate milk supply perceived would be a better criterion for inclusion than exclusion, however, the closest values of $\mathrm{Ii}$ (exclusion index) and $\mathrm{Ei}$ (exclusion index) place this defining characteristic as less useful for the application of the inclusion rule and exclusion than the previous ones. However, its clinical value continues to be valid by the application of other measures, whereas the inability of the infant to seize the nipple region with the mouth is an excellent criterion for the application of the exclusion rule. That is, a greater probability of effective breastfeeding is expected when the infant succeeds in seeing the nipple region correctly.

The accuracy measures and the regression model proposed in the study, relate characteristics that gain clinical value for the nursing evaluation. Thus, it would be important to advise or recommend the mother to observe the following questions: (1) if the child has a good positioning of the mouth during feeding, (2) if during the breastfeeding process the child maintains suction in the (3) if the mother considers that her milk has been sufficient and what reasons she attributes to the lack of sufficiency, and (4) if, after the feeding, she realizes that the child is calm and satiated .

It is worth emphasizing that breastfeeding can be understood as an interactive and dynamic process between motherchild and with complexities that can not be neglected by the nurse. Thus, as pointed out previously, children have multiple reasons to cry, and not all crying children would be experiencing a process of ineffective breastfeeding. In a more systemic perspective of reality, the deepening of the bond and understanding of the child's expressions by the mother could cause comfort responses that would lead to the minimization of crying or even the negative evaluation of the mother regarding the normal and expected crying of the babies ${ }^{(16)}$.

In the study, we defend the relevance of investigating the statistical values of the variables linked to the accuracy of a diagnosis as a whole, to propose statistical and clinical models 
of characteristics that best define the diagnosis and to communicate and discuss results through rules or syntheses that facilitate the clinical application by the service nurses.

\section{Study limitations}

As limitations, the authors acknowledge the need to develop new studies with a greater number of participants and the construction of a relationship with findings from other diagnostic studies. The limit of comparison with other studies - that did not investigate the defining characteristics within the first 48 hours of the infant's life - is also recognized.

Contributions for Nursing, health and public policy areas It is estimated that the findings of this research can contribute to the correct and rapid inference of the diagnosis of "ineffective breastfeeding" in infants, since accuracy studies contribute to indicate the value of test of evaluation clinic evidences (defining characteristics). Indirectly, it tends to reduce nurses' time and energy expenditures for a detailed investigation of signs and symptoms that would have less diagnostic prediction power, thus, collaborating with the optimized realization of the nursing process.

In the broader field, the study aims to contribute to the planning of nursing actions in the joint accommodation of the puerperal and infants, as well as to partially reduce the gap in the nursing literature on nursing diagnoses related to breastfeeding.

\section{CONCLUSION}

The present study establishes an important step to present to the nurses potentialities in the use of the nursing diagnosis with a view to a better evaluation of the mother-child binomial in relation to breastfeeding and, consequently, to promote an organization of care through the individualization of the care in joint housing system.

In order to infer the diagnosis of ineffective breastfeeding, the following clinical indicators were relevant: discontinuance of breast suction; the infant's inability of seizing the nipple region correctly; infant's crying one hour after breastfeeding and inappropriate milk supply perceived.

Based on the findings, nurses are advised to use the standardized nursing language system to make specific and precise diagnoses for each mother-child binomial in order to address breastfeeding during binomial care, and to propose the necessary interventions and evaluate the results obtained in order to help achieve the goal of effective breastfeeding.

It is considered that some recommendations and considerations, derived from the results of the present research, are important:(1) it is important to understand that the breastfeeding process is dynamic and, as such, the evaluations and the diagnostic judgment can undergo modifications as a function of time in which the data is collected;(2) the defining characteristics usually do not dispose alone of predictive power or sufficient explanation so that the nurse can elaborate an accurate clinical judgment only with an indicator being expected that a greater number of characteristics are investigated and gathered for a more precise judgment on the occurrence or not of ineffective breastfeeding;(3) to experiment with the construction of models of clinical indicators (defining characteristics) and rules of use that are capable of better representing the relationships between them and the diagnosis to be characterized.

\section{REFERENCES}

1. Bomer-Norton C. Breastfeeding: A holistic Concept Analysis. Public Health Nurs [Internet]. 2014 [cited 2016 Nov 11];31(1):8896. Available from: http://onlinelibrary.wiley.com/doi/10.1111/phn.12047/pdf

2. Brasil. Ministério da Saúde. Secretaria de Atenção à Saúde. Departamento de Atenção Básica. Saúde da criança: aleitamento materno e alimentação complementar. Cadernos de Atenção Básica. n. 23. 2 ed. Brasília: Ministério da Saúde; 2015.

3. Silva EP, Alves AR, Macedo ARM, Bezerra RMSB, Almeida PC, Chaves EMC. Diagnósticos de enfermagem relacionados à amamentação em unidade de alojamento conjunto. Rev Bras Enferm [Internet]. 2013 [cited 2016 Nov 11];66(2):190-5. Available from: http://www.scielo.br/pdf/reben/v66n2/06.pdf

4. Abrão ACFV, Gutierrez MGR, Marin HF. Diagnóstico de Enfermagem amamentação ineficaz: estudo de identificação e validação clínica. Acta Paul Enferm [Internet]. 2005[cited 2016 Nov 11];18(1):46-55. Available from: http://www.scielo.br/pdf/ape/v18n1/ a07v18n1.pdf

5. Freitas LJQ, Melo NCCC, Valente MMQP, Américo CF, Sousa CSP. Amamentação ineficaz entre as nutrizes atendidas em unidades básicas de saúde. Rev Enferm UERJ [Internet]. 2014 [cited 2016 Nov 11];22(1):103-10. Available from: http://www.e-publicacoes. uerj.br/index.php/enfermagemuerj/article/view/11454

6. NANDA. Diagnósticos de enfermagem da NANDA: definições e classificação 2015-2017 [NANDA Internacional]. Porto Alegre: Artmed; 2015.

7. MedCalc Statistical Software version 15.8. MedCalc Software bvba[Internet]. Ostend: Belgium; 2015 [cited 2016 Nov 11$].$ Available from: https://www.medcalc.org

8. Thompson M, Den Bruel AV. Diagnoson of breastfeeding before 1month of age. Acta Pædiatr [Internet]. 2012 [cited 2016 Nov 11];101:55-60. Available from: http://onlinelibrary.wiley.com/doi/10.1111/j.1651-2227.2011.02405.x/pdf

9. Sanches MTC, Buccini GS, Gimeno SGA, Rosa TEC, Bonamigo AW. Fatores associados à interrupção do AME de lactentes 
nascidos com baixo peso assistidos na atenção básica. Cad Saúde Pública [Internet]. 2011[cited 2016 Nov 11];27(5):953-65. Available from: http://dx.doi.org/10.1590/S0102-311X2011000500013

10. Silveira LM, Prade LS, Ruedell AM, Haeffner LSB, Weinmann ARM. Aleitamento materno e sua influência nas habilidades orais de crianças. Rev Saúde Pública [Internet]. 2013[cited 2016 Nov 11];47(1):37-43. Available from: http://www.scielo.br/pdf/rsp/ v47n1/06.pdf

11. Valerio KD, Araujo CMT, Coutinho SB. Influência da disfunção oral do neonato a termo sobre o início da lactação. Rev CEFAC [Internet]. 2010 [cited 2016 Nov 11];12(3):441-53. Available from: http://www.scielo.br/pdf/rcefac/v12n3/148-09.pdf

12. Stephan AMS, Cavada MN, Vilela CZ. Prevalência de aleitamento materno exclusivo até a idade seis meses e características maternas associadas, em área de abrangência de unidade de saúde da família no município de Pelotas, Estado do Rio Grande do Sul, Brasil. Epidemiol Serv Saúde [Internet]. 2012[cited 2016 Nov 11];21(3):431-38. Available from: http://scielo.iec.pa.gov.br/ pdf/ess/v21n3/v21n3a08.pdf

13. Marques ES, Cotta RMM, Priore SE. Mitos e crenças sobre o aleitamento materno. Ciênc Saude Colet [Internet]. 2011 [cited 2016 Nov 11];16(5):2461-68. Available from: http://www.scielo.br/pdf/csc/v16n5/a15v16n5.pdf

14. Zapana PM, Oliveira MN, Aguiar JÁ, Taddei C. Factores que determinan la lactancia materna en niños matriculados en Jardines Infantiles públicas y filantrópicas en São Paulo, Brasil. Org Ofic Socied Latino-am Nutr [Internet]. 2010 [cited 2016 Nov 11];60(4):360-5. Available from: http://www.scielo.org.ve/pdf/alan/v60n4/art07.pdf

15. Rosa NM, Silva EG, Atalah SE. Factores asociados a la lactancia materna exclusiva. Rev Chil Pediatr [Internet]. 2012 [cited 2016 Nov 11];83(2):161-69. Available from: http://www.scielo.cl/pdf/rcp/v83n2/art07.pdf

16. Primo CC. Teoria de médio alcance de amamentação: tecnologia para o cuidado. [Tese]. Rio de Janeiro: Universidade Federal do Rio de Janeiro, Escola de Enfermagem Anna Nery; 2015. 